\title{
ON HARROD'S NATURAL RATE OF GROWTH AND THE ROLE OF DEMAND: AN EMPIRICAL ASSESSMENT
}

\author{
Estefanía Molerés Regalado \\ Ignacio Perrotini Hernández*
}

\section{Resumen}

El presente artículo parte de la contribución original de Harrod (1939), y procede a contrastar la hipótesis de endogeneidad de la tasa natural de crecimiento del producto vis-à-vis fluctuaciones de la demanda agregada para el caso de las economías del TLCAN (Canadá, Estados Unidos y México). Los resultados empíricos muestran que el producto potencial reacciona ante fluctuaciones en la tasa de crecimiento observada, lo cual sugiere que la deflación puede inducir estancabilización (estancamiento con estabilización), dado que la depresión de la demanda efectiva y el empleo provocan efectos nocivos en la tasa de crecimiento económico observado. La omisión del papel de la demanda no contribuye a una mejor comprensión de los determinantes del crecimiento económico cuando la oferta es elástica.

Palabras clave: crecimiento, medición del crecimiento económico, Estados Unidos, Canadá, México Clasificación JEL: O4, O47, O51, O54

* Graduate student and Professor of Economics respectively, División de Estudios de Posgrado, Facultad de Economía, Universidad Nacional Autónoma de México. Corresponding author's e-mail: $<$ iph@unam.mx>.

We should like to thank Tony Thirlwall for helpful comments on a previous version of this paper. 
Estefanía Molerés / Ignacio Perrotini

\section{Abstract}

Starting from the seminal contribution of Harrod (1939), the current paper tests the hypothesis of endogeneity of the natural growth rate of output vis$\grave{a}$-vis aggregate demand fluctuations for the NAFTA economies (Canada, Mexico and the United States). Empirical results show that potential output reacts to fluctuations in actual growth rates, thus signaling that deflation may lead to stagbilisation (stagnation cum stabilisation) as depression of both effective demand and employment impart deleterious effects on the actual rate of economic growth. Under elastic conditions of the supply-side of the economy, neglect of the role played by demand does not contribute to a better understanding of the determinants of economic growth.

Keywords: growth, measurement of economic growth, United States, Canada, Mexico

JEL Classification: O4, O47, O51, O54

\section{Introduction}

Harrod's (1939) An Essay in Dynamic Theory is commonly taken to be the birth of modern economic growth theory. Perhaps it would be more accurate to think of Harrod's seminal paper as the rebirth of growth theory.

A complete historical panorama would be bound to trace the origin of dynamic analysis back to the great dynamic theories of previous centuries, which would take into account the contributions of the classical political economists -for obvious reasons, this task is not attempted in this paper. Boisguillebert (1695) and Quesnay (1758) described the dynamic functioning of the economic system emphasizing the circulation of wealth; Smith (1776) and Ricardo (1821) elaborated a dynamic model putting forth a theory of capital accumulation-led growth in which, after short-term fluctuations, competition will unravel in a long-term steady state position; Karl Marx (1867, 1894, 1976), following the classical political economists' surplus approach, explained the "laws of motion" (laws of accumulation, tendencies towards increasing concentration and centralization of capital and of impoverishment of working classes, the formal conditions for reproduction, cycles, possibility and determination of crises) of the capitalist economy. The classical surplus approach-based dynamic theory was put aside with 
the advent of the marginalist revolution of the late xIX century led by W.S. Jevons, K. Menger and L. Walras.

In this sense, Roy Harrod deserves credit for reintroducing analytical concerns with growth theory against the historical background of both the Great Depression and the collapse of the Gold Standard of the 1930s. While combining the acceleration principle and the multiplier theory, Harrod attempts to dynamise Keynes's General Theory of Employment, Interest, and Money, he extends Keynes's fundamental concepts to economic growth and explores the required conditions for the achievement of a continuous full employment growth rate of output. Harrod assumes that an economic system is likely to fall into a depression before full employment is reached in the previous boom or to fall into a structural unemployment situation due to an increase in the savings rate. Harrod's seminal contribution gave rise to a widespread debate focused on the existence and the instability problems derived from his dynamic theory. The debate, throughout the poswar period, concentrated mainly on the solution to Harrod's "knife edge" instability problem, while the issue of the nature (exogenous or endogenous) of the natural rate of growth was largely overlooked. This is a topic of paramount importance as far as policy space for economic development is concerned.

The aim of the present paper is to estimate the elasticity of the natural rate of growth with respect to the actual rate of growth in Canada, Mexico and the United States. The hypothesis of an endogenous natural growth rate of output vis-à-vis aggregate demand fluctuations is tested. Hence, if potential output reacts to demand fluctuations, then economic policies that depress effective demand and employment should be expected to impart deleterious effects on the actual rate of economic growth. Our results show that, as expected, the natural rate of growth is endogenous to the actual growth rate of output, suggesting that, under elastic conditions of the supply-side of the economy, neglect of the role of demand does not contribute to a better understanding of the determinants of economic growth.

The paper is so organised. The second section summarises Harrod's contribution and sets the theoretical problem to be explored in the document; the third section contains a brief discussion of the relevant literature on the endogenous approach of the natural growth rate with respect to demand, the fourth one presents the methodology used in section five to estimate the endogeneity of the natural growth rate; the last section concludes. 
Estefanía Molerés / Ignacio Perrotini

\section{Harrod's model, an Outline}

Harrod $(1939$, p. 30) defines the natural rate of growth as "the maximum rate of growth allowed by the increase of population, accumulation of capital, technological improvement and the work/leisure preference schedule, supposing that there is always full employment in some sense". Formally:

$$
g_{n}=\tau+l
$$

Where $\tau$ denotes technical progress and $l$ is the growth of the labour force, both are exogenously given. Harrod's fundamental equation (ibid., p. 18) is as follows:

$$
g_{a}=s / v=\frac{\dot{Y}}{Y}=g_{w}=s / v r
$$

$g_{a}$ and $g_{w}$ stand for the actual and the warranted growth rate of output respectively, $s$ is the propensity to save out of income, $v$ is the actual incremental capital-output ratio or the acceleration coefficient and $v r$ is the required capital-output ratio. Equation (2) shows the conditio sine qua non for a unique Keynesian path of macroeconomic equilibrium.

The stability problem emerges from the fact that there is no a priori guarantee that the actual and the warranted growth rates will converge. Therefore $g_{a} \neq g_{w}$, the unstable nature of $g_{w}$ means that the system will continuously diverge from equilibrium once the economy is disturbed from its warranted growth trajectory. There has been a lengthy debate on Harrod's stability problem, with one important result being the fact that Harrod (1939) did not get an accurate specification of his (disequilibrium) investment function. Actually, many years ahead, in "a companion piece" to his original article, he acknowledged the "excessive rigidity" of his "original equation" since it neglects "the possibility of substitution in the productive process as between capital and other factors" (Harrod, 1960, p. 278). However interesting for business cycle theory, we will not dwell longer on the stability problem as our task here is to unravel the endogeneity of the natural growth rate.

Harrod's model implies the following overall equilibrium solution:

$$
g_{a}=g_{w}=\frac{s}{v r}=g_{n}=\tau+l
$$


Along this path, equilibrium between actual and desired investment and saving is warranted as well as labour-market equilibrium. The main fundamental (existence) problem of Harrod's dynamic theory emerges from equation (3): the equilibrium path shown therein will only occur as a fluke, because in all probability $s / v r \neq \tau+l$. Equilibrium in the labour market will not be attained if $s / v r<\tau+l$, even if equilibrium between saving and investment does exist.

To sum up, if $g_{a}=g_{w}$, capital is fully employed; if $g_{a}=g_{n}$, labour is fully employed and in the best case scenario where $g_{a}=g_{w}=g_{n}$, both capital and labour are fully utilized. Nevertheless, even when it could be possible to achieve equilibrium between $g_{a}$ and $g_{w}$, balance between $g_{a}$ and $g_{n}$ is still needed in order to achieve full employment of capital and labour.

Harrod's paradox received answers from two different quarters: on the one hand, Solow (1956) and Swan (1956) provided a stability of balanced growth approach along the lines of the neoclassical tradition. Solow (1956), in particular, developed a model of a market economy with a single good and a production function with substitutable inputs and a given constant propensity to save. This model, endowed with a mechanism of automatic regulation in the form of flexibility of the capital-output ratio ( $C$ in Harrod's original notation) and flexibility of relative prices, yields global stability and convergence between $g_{w}$ and $g_{n}$. On the other hand, Kaldor $(1955,1957)$ developed a Cambridge post-Keynesian model with differential propensity to save (by type of income, wages and profits) and flexible savings rates (the savings propensity changes with the distribution of income). Changes in income distribution, by allowing the existence and stability of a steady state, adjust $g_{w}$ to $g_{n}$ and a solution to Harrod's paradox is found. ${ }^{1}$ Pasinetti (1962), in turn, amended Kaldor's model, which overlooked the fact that, if workers' savings are positive $\left(s_{w}>0\right)$, they will hold some capital $\left(k_{w}>0\right)$. Pasinetti assumed, instead, differential propensities to save by social classes; he concludes that, in the end, the rate of profit is not determined by the savings behaviour of the wage-earners, but by the growth rate of the economy and capitalists' savings behaviour.

As Harrod (1960, pp. 278-279) revisited his seminal dynamic theory and reconsidered the stability and existence problems put forth therein, he pointed out that "a theory which makes no allowance for the possible variation in $C_{r}$

"Hence the 'warranted' and the 'natural' rates of growth are not independent of one another; if profit margins are flexible the former will adjust itself to the latter through a consequential change in $\pi$ / $Y$ " (Kaldor, 1955-56). 
Estefanía Molerés / Ignacio Perrotini

(the optimum amount of capital required, $v r$ in our notation]) in response to the abundance or shortage of capital disposal is defective in principle". He sought to overcome this weakness of the original paper by considering the role of the rate of interest in the determination of $g_{n}$ :

$$
\begin{gathered}
{ }_{p c} g_{n}=f\left(r_{n}\right), f^{\prime}(?) \text {, i.e., increasing or decreasing function } \\
C_{r}=f\left(r_{n}\right) \text { (decreasing function) }
\end{gathered}
$$

where ${ }_{p c} g_{n}=$ natural rate of growth per capita, $r_{n}=$ natural rate of interest appropriate to $g_{n}$. Then the desired saving propensity is obtained:

$$
S_{r}=C_{r} g_{n}
$$

Thus, Solow's (1956) objection to Harrod's model with regards the absence of substitutability of capital for labour and viceversa is satisfied, according to Harrod (1960).

Yet, allowance of substitutability of factors of production may yield a solution for saving and investment equilibrium, but it needs not lead to convergence between $g_{w}$ and $g_{n}: s / v r=\tau+1$. Harrod (1960, p. 283) clearly states that inclusion of the interest rate does not solve the problem: "it is a quite an open question whether $g_{n}$ will be higher or lower with a lower rate of interest. All depends on the nature of technological innovations". So, it appears that Harrod continued to believe that the conundrum of the existence of a unique path of convergence between $g_{w}$ and $g_{n}$ remained without a proper solution despite the great contributions of Solow-Swan and Kaldor-Pasinetti models in the postwar period.

Harrod (1939) assumed $g_{n}$ was exogenous in the long haul, an assumption that he was to restate in his Second Essay in Dynamic Theory of 1960 (p. 286): "While the natural rate of growth is determined almost entirely exogenously in relation to the variables of the equations and is therefore taken to require a specified amount of saving $\left(s_{r}\right)$, the warranted rate of growth is taken to be determined by the actual rate of saving (s)". What if Harrod had assumed $g_{n}$ was endogenous to aggregate demand in the presence of surplus labour or unemployment and less than full utilization of potential productive capacity? After all, he maintained that in developing countries "over-full demand does not usually arise in consequence of a deficiency of saving" (Harrod, 1960, p. 288). 
The growth theories that emerged as a response to Harrod's paradox sought to provide mechanisms to achieve the equality between $g_{n}$ and $g_{w}$ treating the natural rate of growth as exogenously given and without any response to aggregate demand, like Harrod did. In Solow's model, the workhorse of mainstream dynamic theory in the postwar era, an economy can grow if the population or the level of technology grows. However, none of these factors is explained, they are exogenous and, therefore, economic growth remains unexplained. As a reaction to Solow's solution, models that assumed non decreasing returns, stemming from endogenous technical change, were developed; other models showed increasing returns to scale originated from either learning by doing processes or inter-industrial spillover of know-how. Unlike the original neoclassical theory, these types of models allow for longterm effectiveness of economic policy.

The natural rate of growth would now be represented by the growth of human capital and the technical progress, and the output growth rate along with the capital stock would be determined by these two elements.

Romer (1986), Lucas (1988), Barro (1991), Mankiw et al. (1992), among others, have tried to show, through different definitions of technical progress, that the long-run per capita rate of growth is positive when technology increases continuously because it makes labour more efficient. Yet, if, again, it is assumed that the labour force grows at a constant exogenous rate and that technological growth is exogenous and constant, then the determinants of economic growth remain still unknown. Even though this new gender of endogenous growth models tried to internalize (endogenize) technical progress, they remained exogenous in that they do not show evidence of a possible relationship between the natural rate of growth and the actual rate of growth, neither do they grant any significant role to demand and the determinants of productivity growth are still left unexplained.

A better understanding of real economic dynamics based on an endogenous model perhaps could gain some insight if the demand side were considered as part and parcel of the economic analysis; at the very least, demand might be an important source of changes in labour supply and its productivity. It is true that, in a sense, there cannot be any output without resources, as the supply-side theory assumes. But the fundamental question is what really determines the amount of available resources in an economy. Most importantly, what explains the widespread stylized fact of differential growth rates across the world economy? The received theory cannot account for this fact as it predicts unconditional convergence of growth rates, which 
Estefanía Molerés / Ignacio Perrotini

is utterly at variance with statistical evidence (Thirlwall, 2002). It does not explain either why factor supply and labour productivity growth differ across countries. If the strength of demand exerts some effect on the supply-side of the economy, perhaps a demand approach to output growth can help us explain differential growth worldwide.

\section{A brief survey of the literature}

The main postulate of the endogenous theory of the natural growth rate of output with respect to aggregate demand mantains that potential output $\left(g_{n}\right)$ reacts to fluctuations of the actual growth rate of output $\left(g_{a}\right)$.

Several empirical studies have found evidence supporting the assumption that the growth rate of the supply of labour cannot be considered autonomus or independent from aggregate demand (Thirlwall, 1979; León-Ledesma and Thirlwall, 2002; Perrotini and Tlatelpa, 2003; Vogel, 2009; Lanzafame 2010; Dray and Thirlwall 2010). The growth of the labour force, in both advanced and developing countries largely responds to labour demand growth, especially in the industrial sector.

An important consequence of the assumption of a natural rate of growth sensible or endogenous to demand fluctuations, is that the short-term (the relationship between $g_{a}$ and $g_{w}$ ) and the long-term (the relationship between $g_{n}$ and $g_{w}$ ) results of Harrod's model change sharply. In the shortterm situation, the cyclical upturn can be prolongued even further, thus preventing $g_{n}$ from imposing a limit on economic growth and making demand restrictions (income elasticities of exports and imports, balance of payments equilibrium) the relevant constraints on cyclical expansion (LeónLedesma and Thirlwall, 2002: 110). Regarding the long-term scenario, the endogeneity of $g_{n}$ will prevent the adjustment between $g_{w}$ and $g_{n}$ along the whole business cycle because the latter will move in the same direction as the actual growth rate.

When $g_{w}>g_{n}$, capital is growing faster than labour force in efficiency units, so equilibrium will be reached if $g_{w}$ declines. During slump periods, $g_{n}$ diminishes along with $g_{a}$ because labour force $(l)$ leaves the labour market, and productivity slows down, preventing adjustment (León-Ledesma and Thirlwall, 2002, p. 110). On the contrary, if $g_{n}>g_{w}$ labour force and labour productivity will grow at a faster pace than capital, and equilibrium will necessitate an increase in $g_{w}$. None the less, such adjustment may not occur 
automatically as $g_{n}$ increases along with $g_{a}$ in boom periods, because the labour supply expands (León-Ledesma y Thirlwall, 2002: 111).

There are many mechanisms reflecting the endogeneity of $g_{n}$. When labour demand augments in times of bonanza, labour supply accommodates accordingly in various ways increasing participation rates in booming sectors of the economy. At an observable level, in countries with local inelastic labour supply the length of the working day and/or inmigration rates tend to expand in the short term. History is full of examples confirming the elasticity of the labour supply: postwar Germany and the United States and today's global economy with the incorporation of China's and India's huge labour markets come to mind.

As for labour productivity, Verdoorn's Law (1949) establishes that it is a positive function of the growth rate of industrial output. Increasing returns to scale associated with higher levels of economic activity and technical progress derived from capital accumulation also account for labour productivity reactions to demand fluctuations. A similar type of spillover effects emerge from increasing returns caused by a generalized and interrelated expansion of all economic activities (Young, 1928) and from learning by doing phenomena (McCombie y Thirlwall, 1997, p. 37). Since labour supply and technical change react endogenously to output and aggregate demand movements, the endogeneity of $g_{n}$ makes economic fluctuations more elastic than what is contemplated by exogenous growth theory. Moreover, if the size of the market is a fundamental variable in the determination of different production techniques and the introduction of new technical, product and production process innovations, then the effective (actual) growth of output is a relevant determinant of the growth of labour productivity (Smith, 1776, book I, chapter 1; León-Ledesma and Thirlwall, 1998, p. 6). ${ }^{2}$

The endogeneity of $g_{n}$ is also reflected by its positive correlation with excess labour supply: economies with higher rates of unemployment tend to exhibit higher elasticity of $g_{n}$ with respect to cyclical fluctuations of actual output (León-Ledesma and Thirlwall, 1998; Perrotini and Tlatelpa, 2002). This stylized fact is found in several empirical studies: Thirlwall (2003) carried out an analysis for a sample of 15 OECD countries, his statistical results

2 "If factor inputs (including productivity growth) react endogenously, the growth process among countries can only be appropriately understood in terms of the differences in the strength of demand and demand restrictions" (Thirlwall, 2002, p. 119). 
show an average natural rate of growth of $3.5 \% ; g_{n}$ increases with economic expansions, with higher elasticity in countries such as Greece, Italy, and Japan. Greece and Italy have substantial reserves of labour, whereas Japan's vigorous output expansion induced a rapid technical progress.

Perrotini and Tlatelpa (2003), following León-Ledesma and Thirlwall (1998), analysed $g_{n}$ reactions to $g_{a}$ during the recent economic cycles of the NAFTA economies, Canada, United States and Mexico; their study aimed at assessing the effectiveness of economic policies carried out within an asymmetric framework of trade integration. They conclude that economies with a higher elastic labour supply will exhibit a higher elasticity of $g_{n}$ as output expands.

Finally, Vogel (2009) conducts an empirical study of a set of Latin American countries, confirming the endogeneity of $g_{n}$ possibly related to the presence of large informal sectors, a lower level of economic development, more labour intensive industries and low industrialization levels.

\section{Methodological technique}

The purpose of the econometric analysis is to estimate the responsiveness of $g_{n}$ to changes in the actual rate of growth, $g_{a}$, and test the hypothesis of the endogeneity of the natural growth rate with respect to aggregate demand fluctuations.

First, the natural rate of growth is estimated for all the countries in the sample. Then we verify the response of $g_{n}$ when $g_{a}$ differs from it. The estimation technique of the endogeneity of $g_{n}$ is based on a modification to one of the equations of Okun's law. Since unemployment rates fall (rise) when $g_{a}>g_{n}\left(g_{a}<g_{n}\right)$, it can be argued that the natural rate of growth of the economy is equal to the actual rate of output growth that keeps unemployment constant (León-Ledesma and Thirlwall, 1998, p. 2). If, as a stylized fact, unemployment and growth rates are closely related to one another, the question is to determine the actual growth rate of output that keeps the unemployment rate constant.

Arthur Okun (1962) makes changes in the rate of unemployment, $\Delta \% \mathrm{U}, \mathrm{a}$ linear function of output growth, $g$. This idea suggests the following equation to estimate $g_{n}$ :

$$
\Delta \% \mathrm{U}=\alpha-\beta(g)
$$


where $\% U$ is the percentage rate of unemployment, $\alpha$ is a constant and $\beta$ is the coefficient that measures the elasticity of unemployment $(\mathrm{U})$ with respect to output variations, $g$. If $\Delta \% \mathrm{U}=0$ then $g_{n}=\alpha / \beta$, with $\alpha / \beta$ equal to the growth rate of output required to maintain $U$ stable.

The above modified version of Okun's method provides "a simple technique" to find an expression for $g_{n}$. Yet, as Thirlwall (2003, p. 114) states, the estimation of $\alpha$ and $\beta$ may be biased downwards: $\alpha$ may be biased because workers leave the labour force when $g$ is low, and $\beta$ may also be biased due to "labour hoarding", leading to either underestimated or overestimated coefficients. Thirlwall (2003) maintains it is difficult to distinguish the strength of the ofsetting biases. Hence he suggests reversing the variables as an alternative to circumvent the biasedness problems implicit in equation (7):

$$
g=\alpha_{1}-\beta_{1}(\Delta \% \mathrm{U})
$$

If $\% \mathrm{U}=0$ then $g_{n}=\alpha_{1}$. Unemployment variations are endogenous to output fluctuations, but the estimation of $g_{n}$ can be carried out without any serious problem. Once $g_{n}$ is estimated, deviations from $g_{a}$ can be calculated, i.e., the endogeneity of $g_{n}$ can be verified with the help of a dummy variable $D: D=1$ when $g_{a}>g_{n}\left(g>\alpha / \beta\right.$ in equation (7) and $g>\alpha_{1}$ in equation (8)), and zero otherwise (Thirlwall, 2003, p. 114-115). If the dummy variable is significant, then the actual growth required to keep $U$ constant in times of economic expansion has increased, which implies that $g_{n}$ has increased as well. The estimation of equation (9) helps to confirm the endogeneity, or elasticity, ${ }^{3}$ of $g_{n}$ vis-à-vis variations in aggregate demand:

$$
g=\alpha_{2}+\alpha_{3} D-\beta_{2}(\Delta \% U)
$$

where $g_{n}=\alpha_{2}+\alpha_{3}$ in boom periods. If the new value of $g_{n}$ is significantly higher than its original value ( $\alpha_{1}$ in equation (8)), this means that the required growth rate to keep $U$ constant during expansion periods has risen. Put differently, $g_{n}$ has moved in tandem and in the same direction as $g_{a}$.

This does not imply that $g_{n}$ is a continuous function of $g_{a}$; rather, the above method discriminates out between periods of high and low growth

The elasticity of the $g_{n}$ is the change in the natural growth rate in boom periods vis-à-vis its own level in normal periods of the business cycle. This reflects the elasticity of $g_{n}$ with respect to cyclical upturns. 
Estefanía Molerés / Ignacio Perrotini

where the growth rate varies because of a higher growth rate of labour force in efficiency units. When $g_{a}>g_{n}$, the percentage level of unemployment falls and technical progress improves through the mechanisms described above.

\section{Empirical analysis}

In this section we estimate the elasticity of $g_{n}$ applying the rolling regressions technique $^{4}$ and using data from Mexico, Canada and the United States in normal and boom periods. Equation (8) is used to estimate the elasticity of $g_{n}$ in normal periods and equation (9) for boom periods.

The time span of data varies for each country, as shown in the corresponding graphs. The sources of information are as follows: data for Mexico on unemployment rates were obtained from a non governmental page; for the United States and Canada data were provided by the Labour Force Survey of the OECD.

Figures 1, 2, and 3 illustrate that in periods of expansion $g_{n}$ is greater than $g_{n}$ in normal periods, as expected. This means that in boom periods $g_{a}$ has imparted positive effects on labour force and productivity.

Figure 1 shows the evolution of Mexico's $g_{n}$. It declined both in normal and boom periods in the late seventies and early eighties, then followed a slightly upward path through the rest of the eighties-early nineties; fell again by the mid-nineties and returned to a somewhat positive trend for the rest of the period.

Figure 2 shows the evolution of Canada's $g_{n}$. It has performed mostly negatively, which would suggest a defficiency in demand, albeit it has kept a constant pace over the last twenty years.

Figure 3 shows the evolution of United States' $g_{n}$. Like in Canada's case, a downward trend at the beginning of the period can be observed, though less noticeable. The behaviour of $g_{n}$ in normal and expansion periods has been constant since the end of the eighties. An outlier observation in the subperiod 1976-1991 can be considered more a data problem than a regression problem, as confirmed by several estimations in search of a solution of the problem. Moreover, the data used were compared to the data provided by the original source and they were consistent with each other.

4 The rolling regressions technique consists of estimating an equation in several overlapped sub-periods of equal size. 
On Harrod's natural Rate of Growth AN THE ROLE OF DEMAND: AN EMPIRICAL ASSESSMENT

Figure 1

Mexico: Evolution of $g_{n}$ (normal and expansion periods), 1974-2011

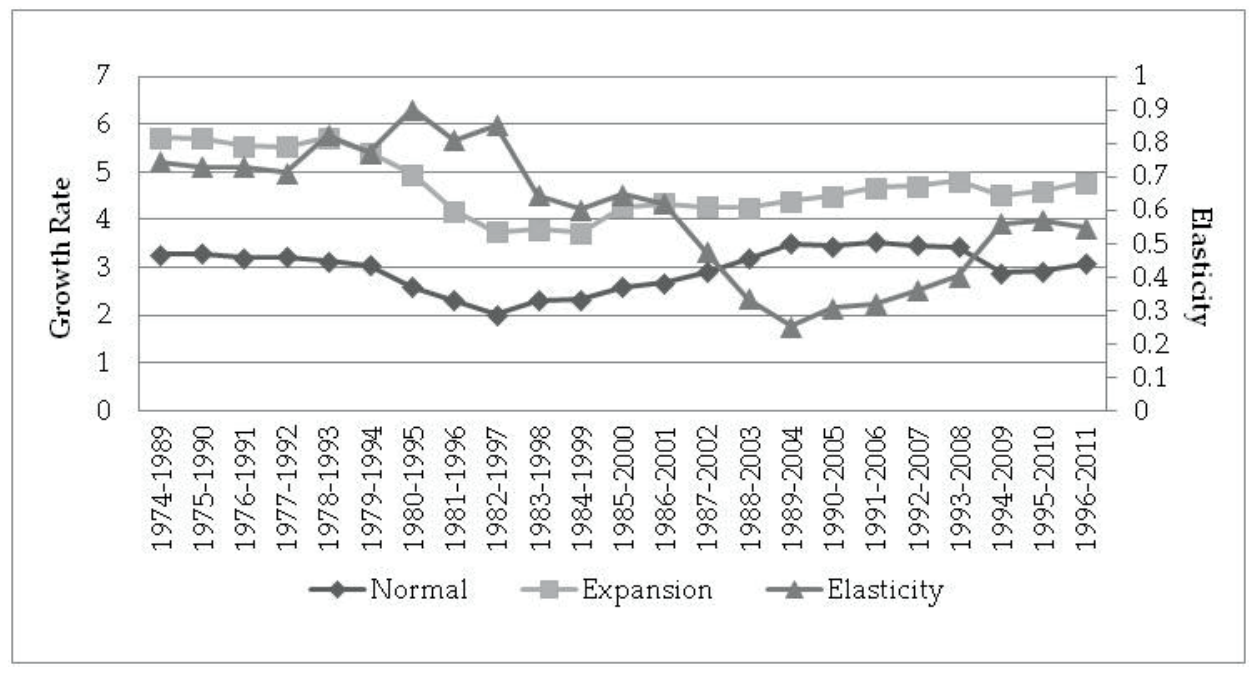

Source: Estimations based on The Mexican Economy Thermometer 1935-2011 and The Conference Board Total Economy Database.

Figure 2

Canada: Evolution of $g_{n}$ (normal and expansion periods), 1971-2011

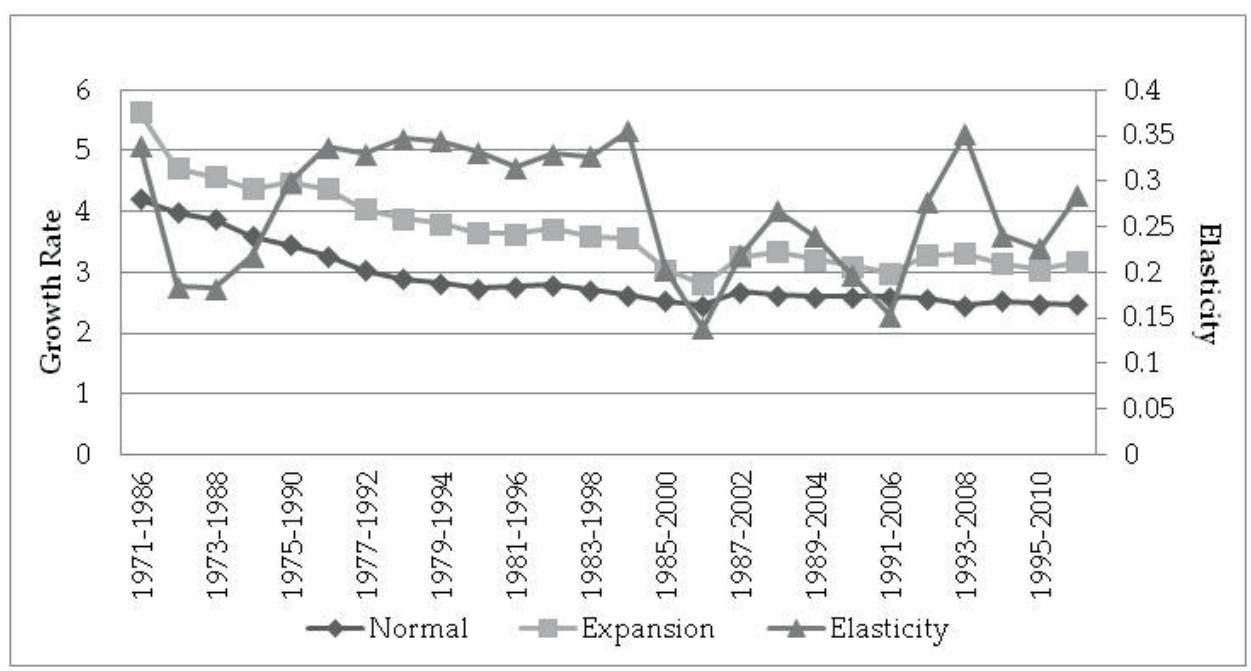

Source: Calculations based on data from OECD and The Conference Board Total Economy Database. 
Figure 3

United States: Evolution of $g_{n}$ (normal and boom periods), 1971-2011

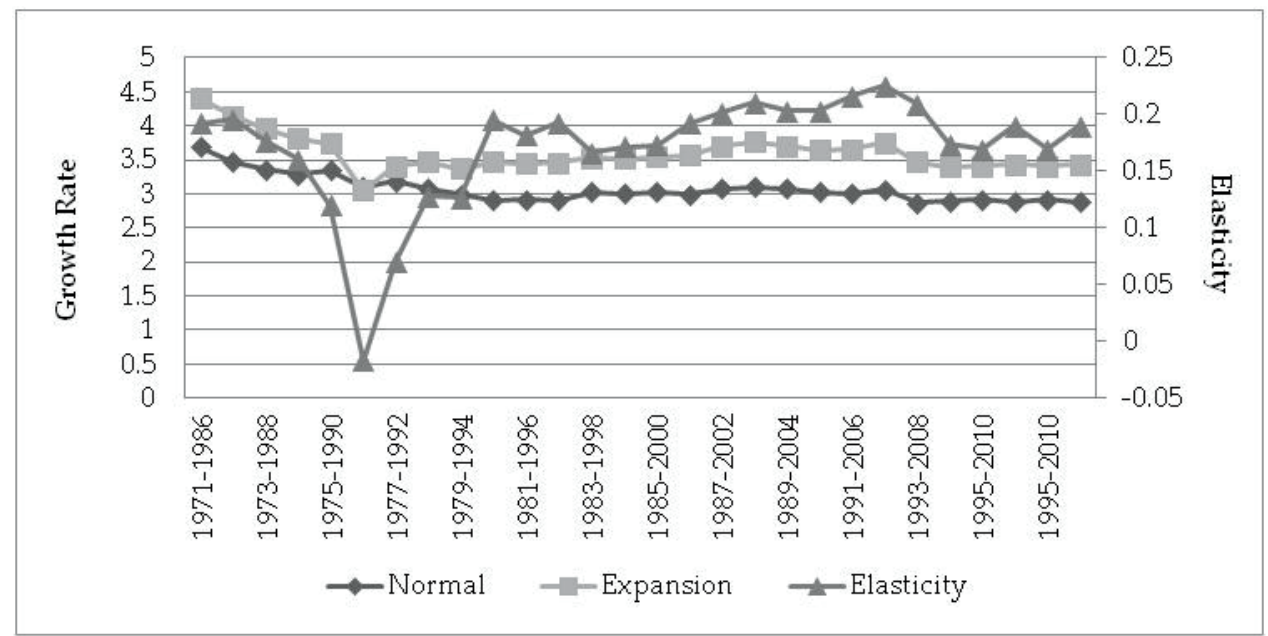

Source: Calculation based on data from the OECD and The Conference Board Total Economy Database.

Estimations are based on equations (8) and (9). In equation (8) the $g_{n}$ estimate is given by the constant term $\alpha_{1}$, which was statistically significant in all three cases. When a dummy variable was included in equation (8) for the years where $g_{a}$ was greater than the estimated $g_{n}$, which resulted in equation (9), the dummy variable was found to be significant for all three cases. The sum of the coefficient of the dummy variable plus the new constant, $\alpha_{2}+\alpha_{3}$, is now the $g_{n}$ in boom periods.

Table 1 summarizes the results of all the estimations; ${ }^{5}$ it can be observed that $g_{n}$ rises in boom periods in comparison to $g_{n}$ in normal periods; $g_{n}$ in normal periods is very similar in all three countries. However, $g_{n}$ in times of expansion is higher in Mexico and, to a lesser extent, in Canada than in the US economy.

Empirical evidence confirms that the discrepancy of $g_{n}$ between normal and boom periods is greater for Mexico than for Canada and (to a higher extent) the United States, most likely due to Mexico's higher rate of unemployment. $g_{n}$ increases noticeably in all three countries, but it does more so in Mexico

\footnotetext{
5 The results of the estimations of equations (8) and (9) can be confirmed in the Appendix at end of document.
} 
than in Canada and the US. The absolute difference is 1.84 in Mexico, 1.22 in Canada, and 0.67 in the United States. This means that the actual rate of growth in expansion has induced labour force and productivity growth by that amount in each country. The elasticity of Mexico's $g_{n}$ is $55.48 \%$, $41.42 \%$ in Canada and $21.6 \%$ in the United States, which would suggest a greater elasticity of Mexico's $g_{n}$. This result is in accordance with Thirlwall's (2002: 118) findings: countries with substantial reserves of labour and where output growth generates a higher rate of productive capacity utilization tend to exhibit elasticity of $g_{n}$. This insight signals policy space for pro-growth actions.

\section{Table 1}

Evolution of $g_{n}$ (normal and expansion periods and elasticity), 1971-2011

\begin{tabular}{cccccc}
\hline Country & $\begin{array}{c}\boldsymbol{g}_{n} \\
\text { in normal } \\
\text { periods } \\
(\mathbf{\% )}\end{array}$ & $\begin{array}{c}\boldsymbol{g}_{n} \\
\text { in expansion } \\
\text { periods } \\
(\mathbf{\% )}\end{array}$ & $\begin{array}{c}\text { Absolute } \\
\text { difference }\end{array}$ & Elasticity & \\
& 3.3317 & 5.1802 & 1.8485 & 0.5588 & 55.4821 \\
\hline Mexico & 3.1379 & 4.4378 & 1.2999 & 0.4143 & 41.4258 \\
Canada & 3.1372 & 3.8161 & 0.6789 & 0.2164 & 21.6403 \\
USA & 3.2023 & 4.4780 & 1.2758 & 0.3965 & 39.5161 \\
\hline Average & & & & & \\
\hline
\end{tabular}

Source: Estimations based on OECD data, The Mexican Economy Thermometer 1935-2011 and The Conference Board Total Economy Database.

The results here reported show a reasonable elasticity of labour force and productivity with respect to demand pressure. Again, signaling the potential positive contribution of sustained demand expansion to $g_{n}$ throughout the cycle (Thirlwall, 2003).

\section{Conclusion}

Starting from the seminal contribution to dynamic theory by Roy Harrod (1939), we have enquired whether $g_{n}$ is endogenous to aggregate demand fluctuations. To this purpose, we applied a "simple technique" introduced 
Estefanía Molerés / Ignacio Perrotini

by A. P. Thirlwall to measure the elasticity of $g_{n}$ of the NAFTA economies. Empirical data shows that labour force and productivity react positively to demand fluctuations in all three economies, while the discrepancies of the corresponding coefficient reactions, both in normal and boom times, crucially depend on idiosyncratic and structural features which, of course, are not mystically given but are liable to alterations by means of appropriate policy measures.

The endogeneity of the $g_{n}$ to demand fluctuations implies that deflation tends to induce a tendency towards productive stagnation and high unemployment rates. Therefore, the elasticity of $g_{n}$ with respect to demand variations hints that inflexible inflation targeting and fiscal consolidation is not the best scenario for entrepeneurial investment, high rates of employment, growth acceleration and monetary and balance of payments stability.

\section{References}

Barro R. (1990), “Government Spending in a Simple Model of Endogenous Growth", Journal of Political Economy, vol. 98, no. 5, Part. 2: The Problem of Development: A Conference of the Institute for the Study of Free Enterprise Systems, S103-S125, (October).

Barro, R. (1991), "Economic Growth in a Cross Section of Countries", Quarterly Journal of Economics, vol. 106, no. 2, pp. 407-443, (May).

Castillo, R. and J. Herrera (2005), "Efecto del gasto público sobre el gasto privado en México", Estudios Económicos, vol. 20, no. 2, 173-196.

Boisguillebert, P. P. (1695), Le détail de la France; la cause de la diminution de ses biens et la facilité du remède, Paris.

Dray, M. and A. P. Thirlwall (2011), "The Endogeneity of the Natural Rate of Growth for a Selection of Asian Countries", Journal of Post Keynesian Economics, M. E. Sharpe, Inc., vol. 33, no. 3, pp. 451-468, (April).

Harrod, R. (1939), "An Essay in Dynamic Theory", Economic Journal, (March). Harrod, R. (1960), "Second Essay in Dynamic Theory", Economic Journal, vol. 70, no. 278, (June), pp. 277-293.

Kaldor, N. (1955-56), "Alternative Theories of Distribution", The Review of Economic Studies, pp. 83-100.

Kaldor, N. (1957), "A Model of Economic Growth", Economic Journal, vol. 67, pp. 591-624.

Keynes, J. (1936), The General Theory of Employment, Interest and Money, BH\&J. 
Lanzafame, M. (2010), "The Endogeneity of the Natural Rate of Growth in the Regions of Italy", International Review of Applied Economics, Taylor and Francis Journals, vol. 24, no. 5, pp. 533-552.

León-Ledesma, M. and A. P Thirlwall (1998), "The Endogeneity of the Natural Rate of Growth", (November), Mimeo.

León-Ledesma, M. and A. P. Thirlwall (2002), “The Endogeneity of the Natural Rate of Growth", Cambridge Journal of Economics, no. 26, pp. 441-459.

León-Ledesma, M. A. and A. P. Thirlwall (2002), "Is the Natural Rate of Growth Exogenous? A Reply", BNL Quarterly Review, no. 221, (June).

Lucas, R. (1988), "On the Mechanics of Economic Development", Journal of Monetary Economics, vol. 22.

Mankiw-Romer-Weil (1992), "A Contribution to the Empirics of Economic Growth", Quarterly Journal of Economics, no. 152.

Marx, K. (1867, 1886, 1894, 1976), Capital, 3 vols., New York, International Publishers.

McCombie, J. S. L, and A. P. Thirlwall (1997), “The Dynamic Harrod Trade Multiplier and the Demand Oriented Approach to Economic Growth: An Evaluation", International Review of Applied Economics, vol. 11, no. 1.

Okun, A. (1962), "Potential GNP: Its Measurement and Significance", Proceedings of the Business and Finance Statistics Section of the American Statistical Association.

Pacheco-López, P. (2009), “Efectos de la liberalización comercial en el crecimiento económico y la balanza de pagos en América Latina", Investigación Económica, vol. 68, no. 267, (Enero-Marzo).

Pasinetti, L. (1962), "Rate of Profit and Income Distribution in Relation to the Rate of Economic Growth", Review of Economic Studies, vol. XXIX, no. 4, pp. 267-279, as reprinted in L. Pasinetti (1974) Growth and Income Distribution: Essays in Economic Theory, Cambridge, UK, Cambridge University Press, pp. 103-120.

Perrotini, I. and D. Tlatelpa (2003), “Crecimiento endógeno y demanda en las economías de América del Norte", Momento Económico, (Julio-Agosto) de 2003, pp. 10-15.

Perrotini, I., J. A. Vázquez and B.L. Avedaño (2008), “In Search of the Developmental State", International Journal of Political Economy, vol. 37, no. 3, (Fall).

Perrotini, I., et al. (2011), Estructura económica y estrategias de crecimiento para América Latina con especial énfasis para México, México, Benemérita Universidad Autónoma de Puebla. 
Estefanía Molerés / Ignacio Perrotini

Quesnay, F. (1758), Tableau économique, Paris.

Ricardo, D. (1817), The Works and correspondence of David Ricardo, vol. VIII, ed. Piero Sraffa with the colaboration of M. H. Dobb, Cambridge, Cambridge University Press, 1951.

Romer, P. (1986), "Increasing returns and long-run growth", Journal of Political Economy, (October).

Romer, P. M. (1994), "The origins of endogenous growth", Journal of Economic Perspectives, vol. 8, no. 1, Winter, pp. 3-22.

Smith, A. $(1776,1976)$, An Inquiry into the Nature and Causes of the Wealth of Nations, Chicago, Chicago University Press.

Solow, R. (1956), "A Contribution to the Theory of Economic Growth", Quarterly Journal of Economics, vol. 70, pp. 65-94.

Swan, T. W. (1956), "Economic Growth and Capital Accumulation”, Economic Record, vol. 32, pp. 334-361.

Thirlwall, A. P. (1994), Economic Growth and the Balance-of-Payments Constraint, Great Britain: Mackays of Chatham.

Thirlwall, A. P. (1995), The Economics of Growth and Development, England: Edward Elgar Publishing Company.

Thirlwall, A. P., and M., Leon-Ledesma (2000), "Is the Natural Rate of Growth Exogenous?", Banca Nazionale del Lavoro Quarterly Review, vol. 53 no. 215, ABI/INFORM Global, (December).

Thirlwall, A. P. (2003), La naturaleza del crecimiento económico, FCE.

Verdoorn, P. J. (1949), “Fattori che regolano los svilluppo della produttività del lavoro", L'Industria, no. 1.

Vogel, L. (2009), "The Endogeneity of the Natural Rate of Growth: An Empirical Study for Latin American Countries", International Review of Applied Economics, vol. 23, no. 1, pp.41-53.

Young, A. (1928), "Increasing returns and economic progress", Economic Journal, (December). 
ON HARRod's NATURAL RATE OF GROWTH AN THE ROLE OF DEMAND: AN EMPIRICAL ASSESSMENT

\section{Appendix of Estimations}

\section{Mexico}

\section{EQUATION (2)}

Dependent Variable: GM

Method: Least Squares

Sample: 19742011

Included observations: 38

\begin{tabular}{lrrrr}
\hline Variable & & & \\
& Coefficient & Std. Error & t-Statistic & \multicolumn{1}{l}{ Prob. } \\
& & & & \\
\hline C & 0.033317 & 0.005024 & 6.632151 & 0 \\
UM & -0.101617 & 0.022842 & -4.448603 & 0.0001 \\
\hline & & & \\
R-squared & 0.354724 & Mean dependent var & 0.032484 \\
Adjusted R-squared & 0.3368 & S.D. dependent var & 0.037999 \\
S.E. of regression & 0.030946 & Akaike info criterion & -4.061978 \\
Sum squared resid & 0.034475 & Schwarz criterion & -3.97579 \\
Log likelihood & 79.17759 & Hannan-Quinn criter & -4.031313 \\
F-statistic & 19.79007 & Durbin-Watson stat & 1.553685 \\
\hline
\end{tabular}

Prob(F-statistic) $\quad 0.00008$

\section{EQUATION (3)}

Dependent Variable: GM

Method: Least Squares

Sample: 19742011

Included observations: 38

\begin{tabular}{lrlrr}
\hline \multicolumn{1}{l}{ Included observations: 38} & & \\
Variable & Coefficient & Std. Error & t-Statistic & \multicolumn{1}{l}{ Prob. } \\
& & & & \\
\hline C & 0.004203 & 0.005866 & 0.716542 & 0.0478 \\
DM1 & 0.047599 & 0.007676 & 6.201052 & 0 \\
UM & -0.064547 & 0.017072 & -3.780771 & 0.0006 \\
\hline & & & & \\
R-squared & 0.692529 & Mean dependent var & 0.032484 \\
Adjusted R-squared & 0.67496 & S.D. dependent var & 0.037999 \\
S.E. of regression & 0.021664 & Akaike info criterion & -4.750645 \\
Sum squared resid & 0.016427 & Schwarz criterion & -4.621362 \\
Log likelihood & 93.26226 & Hannan-Quinn criter. & -4.704647 \\
F-statistic & 39.41599 & Durbin-Watson stat & 1.803387 \\
\hline Prob(F-statistic) & 0 & &
\end{tabular}


Estefanía Molerés / Ignacio Perrotini

\section{Canada}

\section{EQUATION (2)}

\begin{tabular}{|c|c|c|c|c|}
\hline \multicolumn{5}{|c|}{ Dependent Variable: GC } \\
\hline \multicolumn{5}{|l|}{ Method: Least Squares } \\
\hline \multicolumn{5}{|l|}{ Sample: 19712011} \\
\hline \multicolumn{5}{|c|}{ Included observations: 41} \\
\hline Variable & Coefficient & Std. Error & $\mathrm{t}$-Statistic & Prob. \\
\hline $\mathrm{C}$ & 0.031379 & 0.002455 & 12.7839 & 0 \\
\hline $\mathrm{UC}$ & -0.124454 & 0.019215 & -6.476811 & 0 \\
\hline R-squared & 0.518216 & Mean depen & dent var & 0.029668 \\
\hline Adjusted R-squared & 0.505862 & S.D. depend & ent var & 0.022229 \\
\hline S.E. of regression & 0.015626 & Akaike info & criterion & -5.432261 \\
\hline Sum squared resid & 0.009522 & Schwarz crit & terion & -5.348672 \\
\hline Log likelihood & 113.3614 & Hannan-Qui & inn criter & -5.401823 \\
\hline F-statistic & 41.94907 & Durbin-Wats & son stat & 0.72479 \\
\hline
\end{tabular}

\section{EQUATION (3)}

\begin{tabular}{|c|c|c|c|c|}
\hline \multicolumn{5}{|c|}{ Dependent Variable: GC } \\
\hline \multicolumn{5}{|c|}{ Method: Least Squares } \\
\hline \multicolumn{5}{|l|}{ Sample: 19712011} \\
\hline \multicolumn{5}{|c|}{ Included observations: 41} \\
\hline Variable & Coefficient & Std. Error & t-Statistic & Prob. \\
\hline C & 0.020342 & 0.002411 & 8.436463 & 0 \\
\hline DC1 & 0.024036 & 0.003699 & 6.498058 & 0 \\
\hline UC & -0.089204 & 0.014454 & -6.171452 & 0 \\
\hline R-squared & 0.771794 & Mean depen & dent var & 0.029668 \\
\hline Adjusted R-squared & 0.759783 & S.D. depende & ent var & 0.022229 \\
\hline S.E. of regression & 0.010895 & Akaike info $\mathrm{c}$ & criterion & -6.130727 \\
\hline Sum squared resid & 0.00451 & Schwarz crite & erion & -6.005343 \\
\hline Log likelihood & 128.6799 & Hannan-Qui & nn criter & -6.085069 \\
\hline F-statistic & 64.25795 & Durbin-Wats & on stat & 1.429735 \\
\hline
\end{tabular}


On Harrod's natural RATE of GROWTH AN THE ROLE OF DEMAND: AN EMPIRICAL ASSESSMENT

\section{United States}

\section{EQUATION (2)}

Dependent Variable: GU

Method: Least Squares

Sample: 19712011

Included observations: 41

\begin{tabular}{lrrrr}
\hline Variable & Coefficient & Std. Error & t-Statistic & \multicolumn{1}{l}{ Prob. } \\
& & & & \\
\hline C & 0.031372 & 0.001779 & 17.63067 & 0 \\
UU & -0.106088 & 0.010148 & -10.45421 & 0 \\
\hline & & & \\
R-squared & 0.737003 & Mean dependent var & 0.028429 \\
Adjusted R-squared & 0.730259 & S.D. dependent var & 0.021661 \\
S.E. of regression & 0.01125 & Akaike info criterion & -6.089333 \\
Sum squared resid & 0.004936 & Schwarz criterion & -6.005744 \\
Log likelihood & 126.8313 & Hannan-Quinn criter & -6.058894 \\
F-statistic & 109.2905 & Durbin-Watson stat & 1.593779 \\
\hline
\end{tabular}

Prob(F-statistic)

0

\section{EQUATION (3)}

\begin{tabular}{|c|c|c|c|c|}
\hline \multicolumn{5}{|c|}{ Dependent Variable: GU } \\
\hline \multicolumn{5}{|l|}{ Method: Least Squares } \\
\hline \multicolumn{5}{|l|}{ Sample: 19712011} \\
\hline \multicolumn{5}{|c|}{ Included observations: 41} \\
\hline Variable & Coefficient & Std. Error & t-Statistic & Prob. \\
\hline C & 0.022731 & 0.002535 & 8.967847 & 0 \\
\hline DU1 & 0.01543 & 0.003664 & 4.211358 & 0.0002 \\
\hline UU & -0.079509 & 0.010578 & -7.516648 & 0 \\
\hline R-squared & 0.820691 & Mean depen & Ident var & 0.028429 \\
\hline Adjusted R-squared & 0.811253 & S.D. depend & ent var & 0.021661 \\
\hline S.E. of regression & 0.009411 & Akaike info & criterion & -6.423584 \\
\hline Sum squared resid & 0.003365 & Schwarz crit & terion & -6.298201 \\
\hline Log likelihood & 134.6835 & Hannan-Qui & inn criter. & -6.377926 \\
\hline F-statistic & 86.96216 & Durbin-Wat & son stat & 1.808607 \\
\hline
\end{tabular}

